\title{
Hubungan Dukungan Keluarga dan Pemberian ASI dengan Status Gizi Bayi 0-6 Bulan di Wilayah Kerja Puskesmas Trienggadeng Kabupaten Pidie Jaya Tahun 2016
}

\author{
Relationship between Family Support and Breastfeeding with 0-6 Months \\ Infant Nutritional Status in Trienggadeng Health Center Pidie Jaya District \\ 2016 \\ Ulfa Farrah Lisa ${ }^{* 1}$, Cut Arzia ${ }^{2}$ \\ ${ }^{1,2}$ Program Studi D-IV Bidan Pendidik, Fakultas Ilmu Kesehatan, Universitas Ubudiyah Indonesia, Banda Aceh, Indonesia \\ *Korespondensi Penulis: ulfa.feliz@gmail.com
}

\begin{abstract}
Abstrak
Kekurangan asupan gizi pada masa bayi dapat menimbulkan kerusakan otak, letargi, sakit, dan penurunan pertumbuhan fisik. Status gizi dapat ditingkatkan dengan pemberian ASI secara optimal dan dengan adanya dukungan keluarga Dari data Puskesmas Trienggadeng tahun 2015 yang mencakup 27 desa di dapatkan 2 balita $(0,04 \%)$ berstatus gizi buruk,144 balita $(28,8 \%)$ berstatus gizi kurang, dan 354 balita (70,8\%) berstatus gizi baik. Penelitian ini untuk mengetahui hubungan dukungan keluarga dan pemberian ASI dengan status gizi bayi 0-6 Bulan di wilayah kerja Puskesmas Trienggadeng Kabupaten Pidie Jaya Tahun 2016. Jenis penelitian bersifat analitik dengan pendekatan crossectional yang dilakukan wilayah kerja Puskesmas Trienggadeng Kabupaten Pidie Jaya pada tanggal 14 s/d 28 Juli 2016. Jumlah sampel dalam penelitian ini sebanyak 67 orang dengan teknik stratified random sampling. Pengumpulan data menggunakan kuesioner dan uji statistik menggunakan chi-square. Berdasarkan hasil uji statistik, dari 27 responden yang mendapat dukungan dari keluarga status gizi balita mayoritas normal yaitu sebanyak $85,2 \%$, dengan nilai $\mathrm{P}$ value $=0,001$, dan dari 32 responden yang baik dalam pemberian ASI status gizi balita mayoritas normal yaitu sebanyak $75 \%$, dengan nilai $\mathrm{P}$ value $=0,028$. Ada hubungan yang antara dukungan dan pemberian ASI dengan status gizi bayi 0-6 bulan di wilayah kerja Puskesmas Trienggadeng Kabupaten Pidie Jaya Tahun 2016. Untuk itu diharapkan kepada masyarakat di Wilayah Kerja Puskesmas Tringgadeng tentang frekuensi pemberian ASI eksklusif yang benar pada bayi khususnya serta dapat menjadi bahan masukan bagi bidan untuk lebih meningkatkan mutu pelayanan asuhan kebidanan khususnya pada bayi.
\end{abstract}

Kata Kunci: Dukungan Keluarga, Pemberian Asi, Status Gizi

\begin{abstract}
Lack of nutrition during infancy can cause brain damage, lethargy, pain, and decreased physical growth. The nutritional status can be improved by optimal breastfeeding and to support family health center Trienggadeng data from 2015 that includes 27 villages get two
\end{abstract}


toddlers ( $0.04 \%$ ) severe malnutrition, 144 infants ( $28.8 \%$ ) less nutritional status, and 354 infants ( $70.8 \%$ ) well-nourished. This research is to determine the relationship and the Family Support Breastfeeding with Nutritional Status of Infants 0-6 Months ih Trienggadeng Pidie Jaya 2016. This is an analytical research with cross sectional approach undertaken health Trienggadeng Pidie Jaya on 14 s-d 4 July 28, 2016. The number of samples in this study of 67 people with stratified random sampling technique, collecting data using questionnaires and statistical test using chi-square. Based on the statistical test, from 27 respondents who had the backing of the majority of families normal nutritional status is as much as $85.2 \%$, with $P$ value $=0.001$, and of 32 respondents in both the nutritional status of children breastfeeding is normal that the majority of as much as $75 \%$, with the value of $P$ value $=0.028$. There is a relationship between breastfeeding support and the nutritional status of infants 0-6 months $n$ healtTrienggadeng Pidie Jaya Year 2016. For that is expected to communities $n$ health Tringgadeng about the frequency of exclusive breastfeeding is right in infants in particular, and can be input for the midwife to further improve the quality of obstetric care services, especially in infants.

Keywords : Family Support, Providing ASI, Nutritional Status

\section{PENDAHULUAN}

Status gizi merupakan hasil akhir dari keseimbangan asupan gizi yang masuk ke dalam tubuh. Kebutuhan asupan gizi pada bayi berbeda dengan kebutuhan asupan gizi pada orang dewasa, baik dalam jumlah maupun proporsi. Kebutuhan asupan gizi pada bayi akan terus mengalami perubahan seiring pertumbuhannya. Pada bayi 0-6 bulan kebutuhan gizi biasanya sudah tercukupi melalui pemberian ASI secara eksklusif (Riksani, 2012).

Masa bayi sering diistilahkan sebagai periode emas sekaligus periode kritis dimana pada masa ini bayi memerlukan asupan yang sesuai untuk tumbuh kembang optimal. Gizi memegang peranan penting dalam siklus hidup manusia khususnya pada bayi. Kekurangan gizi pada bayi akan menimbulkan gangguan pertumbuhan dan perkembangan yang apabila tidak diatasi secara dini dapat berlanjut hingga dewasa (Depkes, 2010).

Kekurangan asupan gizi pada masa bayi dapat menimbulkan kerusakan otak, letargi, sakit, dan penurunan pertumbuhan fisik. Keempat keadaan ini akan berpengaruh terhadap perkembangan intelektual yang ditandai dengan lambatnya kematangan sel-sel syaraf, lambatnya gerakan motorik, kurangnya kecerdasan dan lambatnya respon sosial (Barus, 2009). Pemberian ASI eksklusif pada bayi selama 6 bulan pertama kehidupannya dapat mencegah terjadinya gizi kurang. DimanaASI mengandung segala kebutuhan bayi seperti karbohidrat berupa laktosa, lemak yang banyak mengandung polyunsaturated fatty acid (asam lemak tak jenuh ganda), protein utama lactal bumin yang mudah dicerna, kandungan vitamin dan mineral yang mengandung rasio kalsium fosfat sebesar 2:1 yang 
merupakan kondisi yang ideal bagi penyerapan kalsium (Yuliarti, 2010).

Masyarakat dan petugas kesehatan perlu memahami pentingnya praktek-praktek pemberian ASI pada bayi yang tepat untuk dapat meningkatkan status gizi pada bayi, keluarga seringkali tidak memiliki pengetahuan tentang ASI, pengetahuan yang tidak memadai dan praktek-praktek yang tidak tepat dapat menghambat peningkatan gizi pada bayi (UNICEF, 2010).

Perilaku ibu dalam pemberian ASI kepada bayi merupakan salah satu faktor yang berhubungan dengan kejadian gangguan gizi pada bayi. Hasil penelitian terhadap ibu diperoleh fakta bahwa yang dapat memberikan ASI eksklusif selama 6 bulan hanya sekitar 5\% padahal 98\% ibu-ibu tersebut menyusui. Dari penelitian juga didapatkan bahwa 37,9\% dari ibu-ibu tersebut tidak pernah mendapatkan informasi dan 70,4\% pernah mendapatkan informasi tentang ASI eksklusif. Kebiasaan menyusu dapat memenuhi kebutuhan gizi bayi serta meningkatkan daya tahan tubuh sehingga membantu pertumbuhan bayi (Roesli, 2011).

Rifka (2009), Pengetahuan juga mempengaruhi kesadaran orang tua untuk menjaga kesehatan anaknya. Sebagai contoh saat bayi atau balita sakit orang tua yang berpengetahuan akan membawa bayi atau balitanya ke dokter, akan tetapi orangtua yang kurang pengetahuan tentang kesehatan justru membawa bayi atau balitanya ke dukun. Kurangnya pengetahuan tentang ASI, gizi dan kesehatan orangtua, khususnya ibu merupakan salah satu penyebab terjadinya kekurangan gizi pada balita Di pedesaan maka banyak dipengaruhi oleh keadaan sosial ekonomi dan kebudayaan, terdapat pantangan makan pada balita misalnya anak kecil tidak diberi ikan karena dapat menyebabkan cacingan, kacang-kacangan juga tidak diberikan karena dapat menyebabkan sakit perut atau kembung (Erna, 2012).

Ibu adalah seorang yang paling dekat dengan anak haruslah memiliki pengetahuan tentang gizi pengetauan minimal yang harus diketahui oleh seorang ibu adalah tentang kebutuhan gizi, cara pemberian makan, jadwal pemberian makan pada balita, sehingga akan menjamin anak dapat tumbuh dan berkembang dengan optimal (Erna, 2012).

Khafiz (2012), masalah gizi mempunyai dimensi yang luas, tidak hanya menyangkut pada aspek kesehatan tapi juga meliputi masalah sosial seperti, ekonomi/ kemiskinan, pengetahuan, pekerjaan, lingkungan, pendidikan dan umur. Jelas sekali bahwa salah satu penyebab terjadinya kekurangan gizi pada balita adalah kurangnya dukungan keluarga, rendahnya pengetahuan, pendidikan dan pendidikan ibu. 
Hasil Pemantauan Status Gizi (PSG) di Nanggroe Aceh Darussalam pada tahun 2015 di dapatkan gizi kurang 5,4\%, gizi buruk 0,6\% dan gizi baik 94\%, sedangkan tingkat Kabupaten Pidie Jaya jumlah balita yang mengalami gizi buruk 7 balita (0,05\%). Gizi kurang sebesar 1259 balita (9,60\%) dari 13.104 balita (Dinkes Pidie Jaya, 2015). Dari data Puskesmas Trienggadeng tahun 2015 yang mencakup 27 desa di dapatkan 2 balita $(0,04 \%)$ berstatus gizi buruk, 144 balita $(28,8 \%)$ berstatus gizi kurang, dan 354 balita $(70,8 \%)$ berstatus gizi baik (Data puskesmas Trienggadeng,2015).

Berdasarkan uraian di atas, jelas sekali diketahui bahwa angka kejadian gizi kurang sangat tinggi di wilayah kerja Puskesmas Trienggadeng yaitu mencapai angka 28,8\%. Oleh karena itu peneliti akan melaksanakan penelitian tentang hubungan dukungan keluarga dan pemberian asi dengan Status Gizi Bayi 0-6 Bulan di wilayah kerja Puskesmas Trienggadeng Kabupaten Pidie Jaya Tahun 2016.

\section{METODE PENELITIAN}

Jenis penelitian ini bersifat analitik dengan desain cross sectional yaitu variabel dependen dan variabel independen dilakukan pada waktu yang sama (Notoatmodjo,2010).Penelitian ini telah dilaksanakan di wilayah kerja Puskesmas Trienggadeng Kabupaten Pidie Jaya pada tanggal 14 Juli s/d 28 Juli 2016.

Populasi di dalam penelitian ini adalahseluruh ibu-ibu yang mempuyai bayi berusia 06 bulan sebanyak 207 orang. Sampel penelitian ini adalah ibu-ibu yang mempunyai bayi umur 0-6 bulan yang berada di wilayah kerja Puskesmas Trienggadeng Kabupaten Pidie Jaya, adapun kriteria inklusifnya yaitu ibu-ibu yang mempunyai bayi umur 0-6 bulan, bayi lahir cukup bulan dengan berat badan lahir cukup.Adapun kriteria ekslusinya bayi memiliki penyakit kongenital dan penyakit kronis yang mengganggu tumbuh kembang.

Teknik pengambilan sampel dalam penelitian ini menggunakan teknik stratified random sampling, yang berjumlah 67 orang. 


\section{HASIL DAN PEMBAHASAN}

Tabel 1. Distribusi Jumlah Sampel ibu-ibu yang Mempunyai Bayi Umur 0 - 6 bulan di Wilayah KerjaPuskesmasTrienggadeng Kabupaten Pidie Jaya Tahun 2016

\begin{tabular}{llcc}
\hline No. & \multicolumn{1}{c}{ Desa } & Populasi & Sampel \\
\hline 1 & DeahPangwa & 17 & 6 \\
2 & Meucat pangwa & 5 & 2 \\
3 & Cot makaso & 4 & 1 \\
4 & Buloh & 0 & 0 \\
5 & Kutapangwa & 5 & 2 \\
6 & Cot LheueRheng & 6 & 2 \\
7 & RawaSari & 13 & 4 \\
8 & Peulandok Tunong & 6 & 2 \\
9 & Peulandok Teungoh & 7 & 2 \\
10 & DeahUjong Baroh & 7 & 2 \\
11 & Matang & 1 & 0 \\
12 & TuengKluet & 11 & 4 \\
13 & Mesjid Trienggadeng & 4 & 1 \\
14 & Meue & 16 & 5 \\
15 & Paya & 4 & 1 \\
16 & Raya & 16 & 5 \\
17 & Keude Trienggadeng & 5 & 2 \\
18 & Dee & 1 & 0 \\
19 & Ruseb & 4 & 1 \\
20 & Tampui & 13 & 4 \\
21 & PantonRaya & 2 & 1 \\
22 & DeahTeumanah & 9 & 3 \\
23 & Sagoe & 20 & 6 \\
24 & MeePeuduek & 5 & 2 \\
25 & MesjidPeuduek & 9 & 3 \\
26 & Tuha & 7 & 2 \\
27 & MeePangwa & 10 & 3 \\
\hline
\end{tabular}

Tabel 2. Distribusi Frekuensi Status Gizi Bayi 0-6 Bulan di Wilayah Kerja Puskesmas Trienggadeng Kabupaten Pidie Jaya Tahun 2016

\begin{tabular}{llcc}
\hline No. & Status Gizi & f & Persentase \\
\hline Normal & 40 & 59,7 \\
Kurus & 27 & 40,3 \\
\hline Total & 67 & 100 \\
\hline
\end{tabular}

Berdasarkan Tabel 2 diatas dapat disimpulkan bahwa yang status gizi normal yaitu sebanyak 40 balita $(59,7 \%)$. 
Tabel 3. Distribusi Frekuensi Dukungan Keluarga Bayi 0-6 Bulan Di Wilayah Kerja Puskesmas Trienggadeng Kabupaten Pidie Jaya Tahun 2016

\begin{tabular}{lcc}
\hline \multicolumn{1}{c}{ Dukungan Keluarga } & f & Persentase \\
\hline Mendukung & 27 & 40,3 \\
Tidak Mendukung & 40 & 59,7 \\
\hline Total & 67 & 100 \\
\hline
\end{tabular}

Berdasarkan Tabel 3 diatas dapat disimpulkan bahwa yang balita yang tidak mendapat dukungan dari keluarga yaitu sebanyak 40 balita $(59,7 \%)$.

Tabel 4. Distribusi Frekuensi Pemberian ASI Bayi 0-6 Bulan Di Wilayah Kerja Puskesmas Trienggadeng Kabupaten Pidie Jaya Tahun 2016

\begin{tabular}{llcc}
\hline No. & Pemberian ASI & f & Persentase \\
\hline Baik & 32 & 47,8 \\
Kurang Baik & 35 & 52,2 \\
\hline Total & 67 & 100 \\
\hline
\end{tabular}

Berdasarkan Tabel 4diatas dapat disimpulkanbahwa yang pemberian ASI dengan kurang baik yaitu sebanyak 35 balita $(52,2 \%)$.

Tabel 5. Hubungan Dukungan Keluarga dan Pemberian ASI dengan Status Gizi Bayi 0-6 Bulan di wilayah kerja Puskesmas Trienggadeng Kabupaten Pidie Jaya Tahun 2016

\begin{tabular}{|c|c|c|c|c|c|c|c|c|}
\hline \multirow{3}{*}{ No. } & \multirow{3}{*}{$\begin{array}{c}\text { Dukungan } \\
\text { Keluarga }\end{array}$} & \multicolumn{4}{|c|}{ Status Gizi Balita } & \multirow{2}{*}{\multicolumn{2}{|c|}{ Total }} & \multirow{3}{*}{$\begin{array}{c}\text { p- } \\
\text { value }\end{array}$} \\
\hline & & \multicolumn{2}{|c|}{ Normal } & \multicolumn{2}{|c|}{ Kurus } & & & \\
\hline & & $\mathbf{f}$ & $\%$ & $\mathbf{f}$ & $\%$ & $\mathbf{f}$ & $\%$ & \\
\hline 1 & Mendukung & 23 & 85,2 & 4 & 14,8 & 27 & 100 & \multirow{3}{*}{0,001} \\
\hline \multirow[t]{2}{*}{2} & Tidak Mendukung & 17 & 42,5 & 23 & 57,5 & 40 & 100 & \\
\hline & Total & 40 & & 27 & & 67 & & \\
\hline
\end{tabular}

Berdasarkan tabel 5 dapat disimpulkan dari 27 responden yang mendapat dukungan dari keluarga status gizi balita mayoritas normal yaitu sebanyak $85,2 \%$, di bandingkan dari 40 responden yang tidak mendapat dukungan dari keluarga status gizi balitia normal yaitu sebanyak 42,7\%. Setelah dilakukan uji statistik maka diperoleh nilai $\mathrm{P}$ value $=0,001$, yang menunjukkan adanya hubungan antara dukungan keluarga dengan status gizi bayi 0-6 bulan di wilayah kerja Puskesmas Trienggadeng Kabupaten Pidie Jaya Tahun 2016. 
Tabel 6. Hubungan Pemberian ASI dan Pemberian ASI dengan Status Gizi Bayi 0-6 Bulan di wilayah kerja Puskesmas Trienggadeng Kabupaten Pidie Jaya Tahun 2016

\begin{tabular}{|c|c|c|c|c|c|c|c|c|}
\hline \multirow{3}{*}{ No. } & \multirow{3}{*}{ Pemberian ASI } & \multicolumn{4}{|c|}{ Status Gizi Balita } & \multirow{2}{*}{\multicolumn{2}{|c|}{ Total }} & \multirow{3}{*}{$\begin{array}{c}\text { p- } \\
\text { value }\end{array}$} \\
\hline & & \multicolumn{2}{|c|}{ Normal } & \multicolumn{2}{|c|}{ Kurus } & & & \\
\hline & & $\mathbf{f}$ & $\%$ & $\mathbf{f}$ & $\%$ & $\mathbf{f}$ & $\%$ & \\
\hline 1 & Baik & 24 & 75 & 8 & 25 & 32 & 100 & \multirow{3}{*}{0,001} \\
\hline \multirow[t]{2}{*}{2} & Kurang Baik & 16 & 45,7 & 19 & 54,3 & 35 & 100 & \\
\hline & Total & 40 & & 27 & & 67 & & \\
\hline
\end{tabular}

Berdasarkan tabel 6 dapat disimpulkan dari 32 responden yang baik dalam pemberian ASI status gizi balita mayoritas normal yaitu sebanyak $75 \%$, di bandingkan dari 35 responden yang kurang baik dalam pemberian ASI status gizi balitia normal yaitu sebanyak $45,7 \%$. Setelah dilakukan uji statistik maka diperoleh nilai $\mathrm{P}$ value $=0,028$, sehingga yang menunjukkan adanya hubungan pemberian ASI dengan status gizi bayi 0-6 bulan di wilayah kerja Puskesmas Trienggadeng Kabupaten Pidie Jaya Tahun 2016.

\section{Pembahasan}

1. Hubungan Dukungan Keluarga dengan Status Gizi Bayi 0-6 Bulan

Berdasarkan hasil penelitian dapatdisimpulkan dari 27 responden yang mendapat dukungan dari keluarga status gizi balita mayoritas normal yaitu sebanyak85,2\%, di bandingkan dari 40 respondenyang tidak mendapat dukungan daru keuarga status gizi balitia normal yaitu sebanyak42,7\%. Setelah dilakukan uji statistik maka diperoleh nilai Pvalue=0,001, yangmenunjukkanadanya hubunganantaradukungan keluarga dengan status gizi bayi0-6 bulan di wilayah kerja PuskesmasTrienggadeng Kabupaten Pidie Jaya Tahun2016.

Penelitian sejalan yang dilakukan olehDian (2014) Dari hasil uji statistik mendapat $\mathrm{p}$ value $=0,015<0,05$, maka Ho ditolaksehingga dapat disimpulkan ada hubungan yang signifikan antara dukungan keluarga dengan pemberian ASI dengan Status Gizi Balia di Puskesmas Pakualaman Kota Yogyakarta Tahun 2014.

Hasil penelitian ini sesuai dengan teori yang dikemukakan oleh Wills (dalam Ftriani,2011) menyatakan bahwa dukungankeluarga akan melindungi individu terhadap efek negatif dari depresi dan dukungan keluarga secara langsung akan mempengaruhi status kesehatan individu.

Dukungan keluarga memiliki beberapa faktor yang mempengaruhinya yaitu 
faktor internal yang terdiri dari tahap perkembangan yang ditentukan oleh usia sesuai dengan tahap perkembangan individu, pendidikan atau tingkat pengetahuan,faktor emosi dan spiritual, sedangkan faktor eksternal terdiri dari praktik di keluarga, faktor sosial ekonomi dan latar belakang budaya yang berbeda.

Dukungan keluarga merupakan suatu proses hubungan antara keluargadengan lingkungan sosialnya yang dapat diakses oleh keluarga yang dapat bersifat mendukung dan memberikan pertolongan kepada anggota keluarga (Friedman, 2010).

Menurut asumsi peneliti bahwa terdapat hubungan antara dukungan keluarga dengan status gizi bayi 0-6 bulan, disebabkan keluarga yang memberikan dukungan dukungan berupa rasa aman, cinta kasih, memberi untuk bersemangat terhadap ibu yang sedang menyusui ASI agar mendapat lebih baik status gizinya. Ini juga sangat berperan dalam peningkatan status gizi bayi oleh karena dengan adanya dukungan keluarga ibu lebih termotivasi dalam memberikan nutrisi terutama ASI Ekslusif kepada bayinya sehingga status gizi bayi ikut meningkat.

\section{Hubungan Pemberian ASI dengan Status Gizi Bayi 0-6 Bulan}

Berdasarkan hasil penelitian menunjukkan bahwa status gizi balita yangnormal banyak dijumpai pada responden dengan pemberian ASI yang baik yaitu 75\% lebih tinggi dengan responden yang pemberian ASI kurang baik hanya 45,7\%. Setelah dilakukan uji statistik maka diperoleh nilai $\mathrm{P}$ value $=0,028$, sehingga Ha diterima atau ada hubungan antara pemberian ASI dengan status gizi bayi 0-6 bulan di wilayah kerja Puskesmas Trienggadeng Kabupaten Pidie Jaya Tahun 2016.

Hasil penelitian sejalan yang dilakukan oleh Pome (2012) yang berjudul "Faktor-Faktor yang berhubungan dengan Status Gizi Balita di Wilayah Kerja UPTD Puskesmas Tanjung Agung Kecamatan Baturaja Barat Kabupaten Oku” didapatkan hasil uji statistik diperoleh nilai $\mathrm{p}=0,009$ (lebih kecil dari alpha 0,05), maka dapat disimpulkan ada perbedaan proporsi status gizi balita pada ibu yang lama pemberian asi kurang dari 2 tahun dengan ibu yang lama pemberian asi lebih dari 2 tahun (ada hubungan yang signifikan antara lama pemberian ASI dengan status gizi balita).

Berbeda dengan penelitian Devi (2010), berdasarkan tabulasi silang persentase status gizi kurang pada ibu yang tidak lagi menyusui lebih tinggi daripada status 
gizi baik, sedangkan pada ibu yang memberikan ASI f persentase status gizi baik lebih tinggi.

Hasil penelitian ini sesuai dengan teori yang dikemukakan oleh (Manuaba, 2008). Air Susu Ibu (ASI) sangat penting bagi bayi, karena ASI merupakan makanan bergizi dan mudah dicerna. Selain itu ASI juga penting bagi perkembangan tubuh dan otaknya. Dalam ASI komposisi kandungan protein, lemak dan karbohidrat sangat mudah dicerna dalam jumlah dan mutu yang dapat diperlukan bayi. Memperhatikan perkembangan pengeluaran bayi, tiada ASI yang tiada berguna. Alam telah mempersiapkan bayi untuk tumbuh kembang hanya dengan ASI sampai umur empat bulan (ASI eksklusif), karena 4 bulan ASI memenuhi semua kebutuhan bayi.

ASI mengandung paling banyak unsur yang tidak ditemukan dalam susu sapi dan tidak dapat ditiru dengan tepat oleh susu formula. Asi dikhususkan untuk masingmasing bayi, bahan mentahnya dipilih dari aliran ibu, sebagaimana yang dibutuhkan, berlanjut dari hari ke hari, saat menyusui selanjutnya. Sementara bayi tumbuh dan berubah gizinya disesuaikan dengan kebutuhan bayinya. Penggantian ASI ke susu formula dari api menyebabkan kekurangan gizi. ASI adalah makanan terbaik yang diberikan pada bayi, dari bayi lahir hingga bayi berumur dua tahun (Roeli, 2008).

Menurut asumsi peneliti bahwa terdapat hubungan antara pemberian ASI dengan status gizi bayi 0-6 bulan, disebabkan kandungan ASI dan Imunologi dan dari ASI terhadap bayi sangat bagus dalam kekebalan tubuhnya kerena dalam ASI juga mengandung lisosom yaitu antibiotic alami dalam ASI yang akan menghancurkan bakteri berbahayanya maka dengan memberikan ASI status balita akan semakin baik. Dan ASI merupakan makanan yang higienis, murah, mudah diberikan, dan sudah tersedia bagi bayi. ASI menjadi satu satunya makanan yang dibutuhkan bayi selama 6 bulan pertama hidupnya agar menjadi bayi yang sehat. Komposisinya yang dinamis dan sesuai dengan kebutuhan bayi men jadikan ASI sebagai asupan gizi yang optimal bagi bayi. ASI dan plasma memiliki konsentrasi ion yang sama sehingga bayi tidak memerlukan cairan atau makanan tambahan. ASI lebih unggul dibandingkan makanan lain untuk bayi seperti susu formula, karena kandungan protein pada ASI lebih rendah dibandingkan pada susu sapi sehingga tidak memberatkan kerja ginjal, jenis proteinnya pun mudah dicerna. 


\section{KESIMPULAN}

1. Ada hubungan antara dukungan keluarga dengan status gizi bayi 0-6 bulan di wilayahkerja Puskesmas Trienggadeng Kabupaten Pidie Jaya Tahun 2016, dengan hasil uji statistik $p$ value $=0,001$.

2. Ada hubungan antara pemberian ASIdengan status gizi bayi 0-6 bulan di wilayah kerja Puskesmas Trienggadeng KabupatenPidie Jaya Tahun 2016, dengan hasil uji statistik $\mathrm{p}$ value $=0,028$.

\section{SARAN}

Diharapkan untuk puskesmas trienggadeng agar petugas kesehatan atau bidan yang bertugas agar dapat memberikan bahan informasi dan memacu petugas kesehatan untuk meningkatkan penyuluhan tentang faktor yang berhubungan status gizi balita dan kepada peneliti lain yang akan mengangkat judul yang sama dalam penelitian ini untuk lebih memperluas ruang lingkup penelitian dan lebih spesifik dalam memilih variabel penelitian agar penelitian selanjutnya menjadi lebih baik.

\section{DAFTAR PUSTAKA}

Arikunto. S, 2010, Prosedur Penelitian Suatu Pendekatan Praktik, Jakarta: Rineka Cipta

Bahiyatun, 2009, Buku Asuhan KebidananNifas Normal, Jakarta: EGC

Budiarto, E, 2012, Biostastistik Untuk Kedokteran dan Kesehatan Masyarakat, Jakarta: EGC

Dian (2014) Hubungan Dukungan dan Pemberian ASI dengan Status Gizi di Puskesams Kota Yogyakarta Tahun2014.

Chomaria. N, 2011, Panduan Terlengkap PascaMelahirkan, Surakarta: Cinta

Depkes, 2006, Pemantauan PertumbuhanBalita, Jakarta: Depkes RI

Nursalam, 2008, Konsep dan Penerapan Metodologi Penelitian Ilmu Keperawatan, Jakarta: Salemba Medika

Notoatmodjo. S, 2010. Metodologi PenelitianKesehatan, Jakarta: Rineka Cipta

Purwanti, H. S., 2011, Konsep Penerapan ASI Eksklusif, Buku Saku Untuk Bidan. Jakarta: EGC.

Pome (2012) yang berjudul "Faktor-Faktor yang berhubungan dengan Status Gizi Balita di Wilayah Kerja UPTD Puskesmas Tanjung Agung Kecamatan Baturaja Barat Kabupaten Oku

Sediaoetama, 2006, Ilmu Gizi Untuk Mahasiswa dan Profesi, Jakarta: Dian Rakyat 
Supriasa, 2009, Penilaian Status Gizi, Jakarta: EGC

UNICEF, 2012, Ringkasan kajian Gizi Ibu DanAnak, Jakarta: Unicef Indonesia

Virgian, B, 2012, Mengapa Menyusui PerluDilindungi, Artikel, Jakarta: FKUI

Widyastuti, 2009, Hubungan Riwayat Pemberian ASI Eksklusif dengan Status Gizi Bayi 6 12 Bulan di Provinsi NTB, Depok: FKM

Wijaya. P., W., 2013, Kapan Waktu Yang Tepat Bagi Si Kecil Diberikan Makanan

Yuliarti, N., 2010, Keajaiban ASI Makanan Terbaik Untuk Kesehatan Kecerdasan dan Kelincahan Sikecil, Jakarta: Andi 